\title{
Insurance Purchase: Price, Product, Promotion and Consumers Attitude Perspectives
}

\author{
OWOLABI, Adenike Olanrewaju \\ Department of Financial Studies (Insurance Programme) \\ Redeemer's University, Ede, Osun State, Nigeria \\ E-mail: owolabi_olanrewaju@yahoo.com
}

AGBOOLA, Omoniyi Oladipupo

Armstrong Insurance Brokers Limited

Lagos, Nigeria

Received: Nov. 30, 2017 Accepted: Dec. 15, 2017 Published: April 2, 2018

doi:10.5296/bmh.v6i1.12944ＵRL: http://dx.doi.org/10.5296/bmh.v6i1.12944

\begin{abstract}
This paper describes the impact of consumer's attitude on the purchase of insurance product in Nigeria. The attitudes, most often negative, are mirrored through low patronage of insurance services. Data were collected through the use of self-structured closed questionnaire. The research adopted a descriptive survey design. One hundred and fifty (150) questionnaires were administered, however only one hundred and thirty two (132) were properly filled and good enough for data analysis. The Pearson Product Moment Correlation and Regression Analysis were used to test the hypotheses generated for the study at 0.05 alpha levels. The result of the study showed that there is a significant relationship between customer's attitude and insurance product. Findings also revealed that there is a significant relationship between product awareness and price. Findings from the survey further revealed that promotion of insurance products have significant influence on consumers buying behavior. Insurance companies are advised to guarantee that their services are dependable and reliable, in that the services should not require an excessive amount of bureaucratic procedure of their customers in taking an insurance policy or getting their claim. Other feasible measures to boost patronage of insurance products were recommended for insurance firms and policy-makers.
\end{abstract}

Keywords: Price, Promotion, Product, Consumers-attitude, Awareness and buying behaviour 


\section{Introduction}

\subsection{The Insurance Industry in Nigeria}

The insurance industry in Nigeria remains largely underdeveloped despite the huge untapped potentials. The strengthening of industry through consolidation in 2007 was designed to make insurance companies viable and able to compete. The Swiss Re in its 2017 global insurance outlook report indicated that the growth of the market in Sub Saharan Africa and specifically Nigeria is relatively slow. Various social and economic factors have been identified as affecting growth in the insurance industry in Nigeria, however, negative attitude towards the industry and poor performance of the companies seem dominant (Yusuf, Gbadamosi, \& Hamadu, 2009). Other challenges affecting consumer attitude towards insurance services include non-payment of claims and insufficient knowledge about insurance industry (Ebitu, Ibok, \& Mbum, 2012), lack of insurance culture (Badru, Yusuf, \& Isola, 2013) insurance fraud (Ojikutu, Yusuf, \& Obalola, 2011) etc.

Delloite in their 2017 report suggested that underinsured market needs to develop new products, services, distribution channels, sales and marketing techniques as essential tools for simulating faster growth. Unfortunately, stimulating growth in a market with negative perception and attitude towards insurance services like Nigeria, requires much more than new products and services. There is need to address the negative attitude of consumers toward insurance services.

Customers' attitudes towards products and services differ, and this affects their purchase decision. Studies on consumer behaviour have examined different factors affecting attitude and how it influences actions (Fishbein \& Ajzen, 1975; Ajzen \& Fishbein, 2005). Attitudes are generally considered as judgments and are results of either direct experience of the social environment or through observations (Vikas \& Mukund, 1998). It is the degree of liking or disliking of an individual towards a particular object, it affects how consumers behave (Fishbein \& Ajzen, 1975; Ajzen \& Fishbein, 2005) and it can influence actions towards insurance products (Yakup, 2014).

Consumers' attitude toward purchase of various financial products has been widely studied especially in the banking sector. For instance, Howcroft, Hamilton, \& Hewer (2002) studied the usage and adoption of home-banking, Lewis \& Soureli (2006) consumer loyalty in retail banking, Lassar \& Manolis (2005) consumer innovativeness and online banking, Lee \& Moelowe (2000) investigated how consumers choose financial institutions. Behavioral insurance literature has also expanded since the studies by Hammond et al. (1967). More studies have gone on to investigate the influence of psychographic and demographic factors on insurance products (Burnett \& Palmer, 1984); search and switching behaviour, and continuous intention.

In Nigeria, studies are also growing in behavioural insurance. Previous studies have examined knowledge and awareness in relation to insurance products, price and promotional activities. In an era of intense competition, where consumers are shying away from difficult-to-understand insurance products and services, and embracing simpler ones, it is not 
yet clear how insurance companies can use product awareness, price and promotional activities to influence consumers' attitude towards insurance product from negative to positive. Earlier studies examined each factor independently, and no study in Nigeria has investigated the combined effect of Product awareness, Promotional activities and Price on consumer attitude towards insurance products.

\subsection{Statement of the Research Problem}

The attitudes of Nigeria consumers toward insurance products are predominantly negative; as said earlier in the background of study, attitude of individual to insurance products differ. Insurance companies should make ready products based on individual persons' attitude. Since many people do not have the idea of insurance, room should be created for promotion of the products, prices of such products should be affordable for both the rich and the poor. The consumers should be keenly studied as regards the aspect of their buying behavior because insurance business is seen or perceived poorly by the Nigeria public. The average Nigerian is of the opinion that the insurance agent who goes around with a briefcase trying to sell insurance policies which are intangible may be excessively high in price. By assessing its role as a major financial intermediary, insurance has become a key source of long term capital and encourage the growth of capital market (Catalan, Gregorio, \& Alberto, 2000; Impavido \& Musalem, 2000). Most Nigerians, both educated and less educated are less enlightened about the importance and benefits of insurance, to worsen the situation apart from the fact that they do not trust the insurance company, they also believe that insurance products are meant for millionaires because they are very expensive. Real work need to be done in these areas. They need to know that insurance products are very cheap and simple to operate and that insurance policy is about the best thing that can happen to any human being.

\subsection{Research Hypothesis}

$\mathbf{H}_{\mathbf{0 1}}$ : There is no significant relationship between customer's attitude and insurance product.

$\mathbf{H}_{\mathbf{0 2}}$ : There is no significant relationship between product awareness and price

$\mathbf{H}_{03}$ : Promotion of insurance product does not have significant influence on consumers buying behavior.

\subsection{Significance of the Study}

The study of consumer behavior is very important to the marketers because it enables them to understand and predict buying behavior of consumers in the marketplace. The study shall contribute to knowledge in the area of customer's awareness of insurance firms, to identify insurance among non-users and price should be based on how much customers actually value the product or service. They should also make use of pricing strategy. It will help the marketers to understand how consumers think, feel, and select from alternative like products brands and how the consumers are influenced by their environment, the reference group, family etc. The company should be able to create awareness for consumers to know about the product. 


\subsection{Scope of the Study}

The major area of concentration of the study will be restricted to productivity, detection and checks of consumer's attitude towards purchasing of insurance product. The research will be carried out in Sovereign trust insurance company at victory inland Lagos state since there is adequate access to information about customers buying behavior, pricing, customer's awareness, insurance product and promotion of insurance product.

\section{Literature Review}

\subsection{Concept, Theory and Empirical Framework}

Price: Price is the amount of money expected, required, or given in payment for something. Price optimization refers to a process or technique used in many industries to help determine what a company will charge for its product or service. In insurance, this process helps insurers fine-tune the premium it will charge for a policy. Insurance companies employ actuaries who use actual loss and expense data to estimate a range of reasonable rates and, within those boundaries, management determines the final rates will be charged. Some insurers have begun to use sophisticated optimization models to help them ascertain appropriate pricing. The general perception about the insurance industry is by and large flawed in that, they sell policies and make substantial profits like any other product off the counter. The reality is far more complex and the pricing of products is no easy task but a long-drawn exercise involving market analysis, past claims history and a collaborative effort amongst underwriters, actuaries and the marketing teams. The post detarrification era has been witness to plunging margins due to the huge discounts offered among competitors. Making profits in commercial as well personal lines insurance has increasingly become a difficult task.

Many insurance companies are now altering their marketing strategy by saying no to irrational competition and developing the competencies to maintain a balance between sustainable retention and value for money for the consumer.

Promotion: For different industries promotion has different aspects. The promotional strategy adopted by any company is informing, persuading, and influencing in consumers decision making. It is important for nonprofit and profit oriented organization. The main objective of promotional strategy is: To expand the market. To sustain the current market position. To reach a selected market. To provide information to customer for differentiating between product and services. To increase and stabilize the sale. Different organizations have different and multiple promotional strategy. Today all insurance companies rely on promotional strategy as it is one of the important tools to provide competitive advantage in this competitive world.

Product: Insurance products can be divided into two. These are: Life and Non-Life businesses. These two can also be further subdivided into various groups.

Consumers Attitude: Consumers are individuals with likes and dislikes. When the preponderance of people in a particular group feel one way or another about a product, service, entity, person, place or thing, it is said to be a generalized consumer attitude that could affect the marketing of that person, product or entity in positive or negative ways. Marketers strive to 
influence consumer attitudes, and understanding the prevailing attitude is the first step to changing it if needed. Consumer attitudes are both an obstacle and an advantage to a marketer. An attitude in marketing terms is defined as a general evaluation of a product or service formed over time (Solomon, 1995). An attitude satisfies a personal motive-and at the same time, affects the shopping and buying habits of consumers.

Awareness: The understanding by an individual of their rights as a consumer concerning available products and services being marketed and sold. The concept involves four categories including safety, choice, information, and the right to be heard. The three stages of consumer awareness are: i. Creating awareness of the need/problem: At this stage the customer is both product and brand agnostic; they do not realize they have a problem or need which requires a solution. Your job at this stage is to show them that they have a problem or need.

ii. Demonstrate the basic solution to that need/problem: At this stage the customer is still brand agnostic; they are now aware of the problem but not yet sure what the solution is. Your job at this stage is to present your solution as the best way to solve their problem or meet their needs. iii. Sell your solution and your brand as the best version: At this stage, the customer knows they have a problem, and they know their preferred approach to solving the problem is through using the product or service that you provide. Your job now is to show that they should choose to buy that solution from you, and to link that solution with your brand in the customer's mind.

Buying Behaviour: The buying behavior of a consumer is the decision processes as well as the actions the consumer takes in buying and using products. Whether or not the consumer realizes it, there is far more that goes into the buying process than simply driving to the store and picking something off the shelf. There are mental and social processes that consumers go through that proceed the actual act of purchasing.

\section{Decision Making Theory}

The theory was propounded by Levi (1974). This theory encompasses a body of knowledge and related analytical techniques of different degrees of formality designed to help a decision maker choose among a set of alternatives in light of their possible consequences. Decision theory can apply to conditions of certainty and uncertainty. This means that each alternative leads to one and only one consequence and a choice among alternatives is equivalent to a choice among consequences; implying that an individual that does not purchase health insurance may likely face certain consequences like paying higher price when illness occurs and poor health status. In the same way, purchasers may enjoy some basic benefits like paying less and getting certain privileges at the end of the year. The knowledge of these aforementioned conditions (payment of higher price for health-when health insurance is not in place, benefits derived from the purchase of health insurance scheme and poor health status) could enhance individual decision whether to purchase health insurance or not. 


\section{Contract Theory}

An insurance policy is a contract between an insurer and an individual. Within the duration of this contract, the individual agrees to exchange income in the form of a premium for a reduction in price for certain insurance services in the event of loss.

Despite the importance of insurance and its validity, the survival of this business in Nigeria has been a serious challenge. "Market statistics revealed the poor performance of insurance business in Nigeria, it was discovered that Nigeria insurers cover less than five percent of the nation's insurable population" (Usman, 2009; Akinbola \& Issac, 2010). Obaremi reported in 2007 that weakness in Nigeria Insurance sector meant that large percentage of their business is underwritten in foreign countries. Many of the strong industries in the country are more comfortable to have their risk carried by foreign insurers. Multinational companies and oil and gas operators in Nigeria insure their major risk overseas due to lack of confidence in Nigeria insurers as they default in claims settlement and other financial obligations to the public (Uranta, 2004 cited by Aduloju, Awoponle, \& Oke, 2008). Some of the challenges faced by insurance business in Nigeria according to Aghoghovbia (2005) are; "lack of skilled man power, difficulties in collection of premium, lack of innovation by insurers and low level of information technology leverage in the industry. He went further by saying that the emergence of universal banking which has expanded the scope of banking to include a good measure of insurance services is a serious threat to the insurance business". The low insurance penetration in Nigeria compare to other countries in Africa is due to challenges facing this business such as market penetration, improved product distribution, local content policy especially oil and gas, prompt claim settlement, competent management, corporate governance, innovative products, adequate technology, and the competitive structure of the industry which is said to be compounded by the large number of insurance brokers (Albert cited by The Punch, 2010). The players in this market are too many and they do not have competitive products. Daniels cited in The Report: Nigeria (2010) asserted that "a single insurance company in developed countries generates 232.0 billion USD ( $\$ 34.8$ trillion) insurance premium every year and employs 120,000 employees. The entire insurance companies in Nigeria struggle to generate only 200.0 billion NGN and employ only 25,000 employees". "The survival and performance of insurance business in Nigeria is threatened by the poverty level among the populace, citizen's religious belief, crime and fraudulent practices in the industry and poor service culture by insurers" (Olaleye \& Adegoke, 2009). "Nigeria is said to be a religious conscious country and the people believe that the God they serve is more than insurance. In other words, God is their insurance. Some identified "problems affecting this business from the literature reviewed from past researchers and different scholars in this field are: Ethical issue, Poor premium collection, Solvency problem/low liquidity, Lack of standard, Absence of government, Poor management, Low level of information technology, Lack of integrity/trust, Attitudes of Nigerians toward insurance services, and Lack of innovation". 


\section{Methods}

The statistical test of Simple Linear Regression Analysis and Pearson Correlations was employed. One hundred and fifty (150) questionnaires were administered, however only one hundred and thirty (132) were properly filled and good enough for data analysis. The statistical results that were obtained are presented in this section. Descriptive as well as the inferential statistics are both presented.

\section{Data Analysis}

4.1 Analysis of Data Related to the Impact of Consumers Attitude on the Purchase of Insurance Products in Nigeria

Table 1. Consumers attitude

\begin{tabular}{|c|c|c|c|c|c|c|c|c|c|c|}
\hline & \multicolumn{2}{|c|}{ Strongly Agree } & \multicolumn{2}{|c|}{ Agree } & \multicolumn{2}{|c|}{ Undecided } & \multicolumn{2}{|c|}{ Disagree } & \multicolumn{2}{|c|}{$\begin{array}{l}\text { Strongly } \\
\text { Disagree }\end{array}$} \\
\hline & Freq. & Percent & Freq. & Percent & Freq. & Percent & Freq. & Percent & Freq. & Percent \\
\hline $\begin{array}{ll}\begin{array}{l}\text { Premium has a } \\
\text { relationship }\end{array} & \text { direct } \\
\text { consumers attitude } & \\
\end{array}$ & 26 & 19.70 & 38 & 28.79 & 17 & 12.88 & 32 & 24.24 & 19 & 14.39 \\
\hline $\begin{array}{l}\text { Impersonal use of } \\
\text { advertising and publicity } \\
\text { will change my attitude } \\
\text { towards purchasing of } \\
\text { insurance product in } \\
\text { Nigeria }\end{array}$ & 24 & 18.18 & 51 & 38.64 & 11 & 8.33 & 29 & 21.97 & 17 & 12.88 \\
\hline $\begin{array}{l}\text { Insurance help to provide } \\
\text { same standard of living } \\
\text { for dependents in case of } \\
\text { death or disability of } \\
\text { policy holder }\end{array}$ & 29 & 21.97 & 36 & 27.27 & 10 & 7.58 & 34 & 25.76 & 23 & 17.42 \\
\hline $\begin{array}{l}\text { Obtaining insurance } \\
\text { product is not a necessity }\end{array}$ & 27 & 20.45 & 34 & 25.76 & 25 & 18.94 & 30 & 22.73 & 16 & 12.12 \\
\hline $\begin{array}{l}\text { Insurance product is for } \\
\text { rich people in the country }\end{array}$ & 22 & 16.67 & 47 & 35.61 & 13 & 9.85 & 32 & 24.24 & 18 & 13.64 \\
\hline
\end{tabular}

Source: Computed by Author.

In describing consumers attitude towards insurance products in Nigeria, the people living in Lagos State that participated in this study portray the unhealthy attitude of consumers towards insurance products in Nigeria, this is evidence from their responses presented in Table 1; 48.49\% of the 132 respondents concurred (Strongly Agree and Agree) that "premium has a direct relationship with consumers attitude" compare to the $38.63 \%$ that disagreed (Strongly Disagree and Disagree), 56.82\% concurred (Strongly Agree and Agree) that "impersonal use of advertising and publicity will change their attitude towards purchasing of insurance product in Nigeria", 49.24\% concurred (Strongly Agree and Agree) that the "insurance help to provide same standard of living for dependents in case of death or disability of policy holder" compare to the $43.18 \%$ that disagreed (Strongly Disagree and Disagree), $46.21 \%$ concurred (Strongly Agree and Agree) that "obtaining insurance product 
is not a necessity" compare to the $34.85 \%$ that disagreed (Strongly Disagree and Disagree), and $52.28 \%$ concurred (Strongly Agree and Agree) that the "insurance product is for rich people in the country" as reflected in Table 1.

Table 2. Customers awareness

\begin{tabular}{|c|c|c|c|c|c|c|c|c|c|c|}
\hline & \multicolumn{2}{|c|}{ Strongly Agree } & \multicolumn{2}{|l|}{ Agree } & \multicolumn{2}{|c|}{ Undecided } & \multicolumn{2}{|c|}{ Disagree } & \multicolumn{2}{|c|}{$\begin{array}{l}\text { Strongly } \\
\text { Disagree }\end{array}$} \\
\hline & Freq. & Percent & Freq. & Percent & Freq. & Percent & Freq. & Percent & Freq. & Percent \\
\hline $\begin{array}{l}\text { I have adequate knowledge of } \\
\text { insurance products }\end{array}$ & 13 & 9.85 & 38 & 28.79 & 17 & 12.88 & 40 & 30.30 & 24 & 18.18 \\
\hline $\begin{array}{l}\text { Enlighten of insurance product } \\
\text { will increase purchase of } \\
\text { insurance products }\end{array}$ & 21 & 15.91 & 46 & 34.85 & 13 & 9.85 & 28 & 21.21 & 24 & 18.18 \\
\hline $\begin{array}{l}\text { Awareness of insurance product } \\
\text { increases the sales in insurance } \\
\text { companies }\end{array}$ & 28 & 21.21 & 33 & 25.00 & 15 & 11.36 & 26 & 19.70 & 30 & 22.73 \\
\hline $\begin{array}{l}\text { The awareness of insurance } \\
\text { rules does not affect my attitude } \\
\text { towards insurance products }\end{array}$ & 16 & 12.12 & 32 & 24.24 & 23 & 17.42 & 42 & 31.82 & 19 & 14.39 \\
\hline
\end{tabular}

Source: Computed by author.

Table 2 unveil the the level of awareness of customers on insurance products in Nigeria, those residing in Lagos State that partook in this study shows poor awareness of insurance products in Nigeria; majority (48.48\%) of the 132 respondents claimed not to have adequate knowledge of insurance products, 50.76\% affirmed (Strongly Agree and Agree) that "enlighten of insurance product will increase purchase of insurance product", majority (46.21\%) affirmed (Strongly Agree and Agree) that "awareness of insurance product increases the sales of insurance companies", and majority (46.21\%) of the 132 respondents disagreed (Disagree and Strongly Disagree) that "the awareness of insurance rules does not affect their attitude towards insurance product".

Table 3. Insurance product

\begin{tabular}{|l|l|l|l|l|l|l|l|l|l|l|l|}
\hline & Strongly Agree & \multicolumn{2}{l|}{ Agree } & \multicolumn{2}{l|}{ Undecided } & \multicolumn{2}{l|}{ Disagree } & \multicolumn{2}{l|}{ Strongly Disagree } \\
\cline { 2 - 10 } & Freq. & Percent & Freq. & Percent & Freq. & Percent & Freq. & Percent & Freq. & Percent \\
\hline $\begin{array}{l}\text { The selling and profit of an } \\
\text { individual product may not } \\
\text { follow the life cycle pattern }\end{array}$ & 21 & 15.91 & 41 & 31.06 & 24 & 18.18 & 28 & 21.21 & 18 & 13.64 \\
\hline $\begin{array}{l}\text { Consumers may not see the } \\
\text { product as offering superior } \\
\text { alternative to whatever they are } \\
\text { currently using }\end{array}$ & 24 & 18.18 & 32 & 24.24 & 15 & 11.36 & 32 & 24.24 & 29 & 21.97 \\
\hline $\begin{array}{l}\text { A good marketing manager know } \\
\text { that a company marketing needs } \\
\text { usually to be kept constant over } \\
\text { the product life cycle }\end{array}$ & 29 & 21.97 & 49 & 37.12 & 14 & 10.61 & 23 & 17.42 & 17 & 12.88 \\
\hline
\end{tabular}

Source: Computed by Author. 


\section{Al Macrothink}

Business and Management Horizons

ISSN 2326-0297

2018, Vol. 6, No. 1

Table 3 reflects the opinion of the people of Lagos state that partook of this study about insurance product; most (46.97\%) of the 132 respondents agreed (Strongly agree and agree) that "the selling and profit of an individual product may not follow the life cycle pattern", most (46.21\%) of the respondents disagreed (Disagree and Strongly Agree) that "consumers may not see the product as offering superior alternative to whatever they are currently using", and $59.09 \%$ of the 132 respondents concurred (Strongly Agree and Agree) that "a good marketing manager know that a company marketing needs usually to be kept constant over the product life cycle".

Table 4. Promotion

\begin{tabular}{|c|c|c|c|c|c|c|c|c|c|c|}
\hline & \multicolumn{2}{|c|}{ Strongly Agree } & \multicolumn{2}{|l|}{ Agree } & \multicolumn{2}{|c|}{ Undecided } & \multicolumn{2}{|c|}{ Disagree } & \multicolumn{2}{|c|}{$\begin{array}{l}\text { Strongly } \\
\text { Disagree }\end{array}$} \\
\hline & Freq. & Percent & Freq. & Percent & Freq. & Percent & Freq. & Percent & Freq. & Percent \\
\hline $\begin{array}{l}\text { Low personal use of } \\
\text { advertising and publicity can } \\
\text { change my attitude towards } \\
\text { insurance product }\end{array}$ & 23 & 17.42 & 27 & 20.45 & 19 & 14.39 & 24 & 18.18 & 39 & 29.55 \\
\hline $\begin{array}{l}\text { A forward looking insurance } \\
\text { company must adopt a change } \\
\text { in attitude in terms of prompt } \\
\text { and responsive payment of } \\
\text { claims }\end{array}$ & 21 & 15.91 & 38 & 28.79 & 23 & 17.42 & 28 & 21.21 & 22 & 16.67 \\
\hline $\begin{array}{l}\text { Insurance companies in } \\
\text { Nigeria are growing. }\end{array}$ & 26 & 19.70 & 35 & 26.52 & 20 & 15.15 & 29 & 21.97 & 22 & 16.67 \\
\hline $\begin{array}{l}\text { Telecommunication promote } \\
\text { the insurance product in } \\
\text { Nigeria }\end{array}$ & 18 & 13.64 & 42 & 31.82 & 28 & 21.21 & 25 & 18.94 & 19 & 14.39 \\
\hline $\begin{array}{l}\text { The government has a greater } \\
\text { impact on the promotion of } \\
\text { the insurance product }\end{array}$ & 36 & 27.27 & 57 & 43.18 & 0 & 0.00 & 14 & 10.61 & 25 & 18.94 \\
\hline
\end{tabular}

Source: Computed by author.

Describing the promotion of insurance products in Nigeria, the 132 participants of this study registered their observations; most $(47.73 \%)$ of the respondents disagreed (Disagree and Strongly Agree) that "low personal use of advertising and publicity can change my attitude towards insurance product", most (44.7\%) of the 132 respondents agreed (Strongly Agree and Agree) that "a forward looking insurance company must adopt a change in attitude in terms of prompt and responsive payment of claims", most (46.22\%) agreed (Strongly Agree and Agree) that "insurance companies in Nigeria are growing", most (45.46\%) of the respondents agreed (Strongly Agree and Agree) that there is rehabilitation management system in their organization, 72.09\% agreed (Agree and Strongly Agree) that "telecommunication promote the insurance product in Nigeria", and 70.45\% agreed (Strongly Agree and Agree) that "the government has a greater impact on the promotion of the insurance product". 
Table 5. Price

\begin{tabular}{|l|l|l|l|l|l|l|l|l|l|l|}
\hline & \multicolumn{2}{|l|}{ Strongly Agree } & \multicolumn{2}{l|}{ Agree } & \multicolumn{2}{l|}{ Undecided } & \multicolumn{2}{l|}{$\begin{array}{l}\text { Sisagrongly } \\
\text { Disagree }\end{array}$} \\
\cline { 2 - 11 } & Freq. & Percent & Freq. & Percent & Freq. & Percent & Freq. & Percent & Freq. & Percent \\
\hline $\begin{array}{l}\text { Price should always be based on } \\
\text { how much customers actually } \\
\text { valve the product or service }\end{array}$ & 32 & 24.24 & 43 & 32.58 & 6 & & 31 & & 20 & \\
\hline $\begin{array}{l}\text { Many insurance company } \\
\text { makes used of pricing strategy } \\
\text { i.e., loyalty cards or buying 10 } \\
\text { and get one free cards }\end{array}$ & 28 & 21.21 & 48 & 36.36 & 13 & & 25 & & 18 & \\
\hline $\begin{array}{l}\text { People are very price sensitive } \\
\text { to insurance products. }\end{array}$ & 30 & 22.73 & 41 & 31.06 & 16 & 12.12 & 29 & 21.97 & 16 & 12.12 \\
\hline $\begin{array}{l}\text { Great product and service } \\
\text { don't guaranty success they also } \\
\text { have to price them correctly }\end{array}$ & 25 & 18.94 & 39 & 29.55 & 23 & & 27 & & 18 & \\
\hline $\begin{array}{l}\text { It is better for insurance coy to } \\
\text { know the customers well and } \\
\text { what they are willing to pay }\end{array}$ & 21 & 15.91 & 46 & 34.85 & 19 & & 31 & & 15 & 13.64 \\
\hline
\end{tabular}

Source: Computed by author.

In describing the pricing of insurance products in Nigeria, the people living in Lagos State that participated in this study portray the relationship between price and insurance products in Nigeria; $56.82 \%$ of the 132 respondents concurred (Strongly Agree and Agree) that "price should always be based on how much customers actually valve the product or service", 57.57\% concurred (Strongly Agree and Agree) that "many insurance company makes used of pricing strategy .i.e. loyalty cards or buying 10 and get one free cards", 53.79\% concurred (Strongly Agree and Agree) that "people are very price sensitive to insurance products", $48.49 \%$ concurred (Strongly Agree and Agree) that "great product and service don't guaranty success they also have to price them correctly", and 50.76\% concurred (Strongly Agree and Agree) that "it is better for insurance coy to know the customers well and what they are willing to pay" as reflected in Table 5.

Table 6. Consumers buying behavior

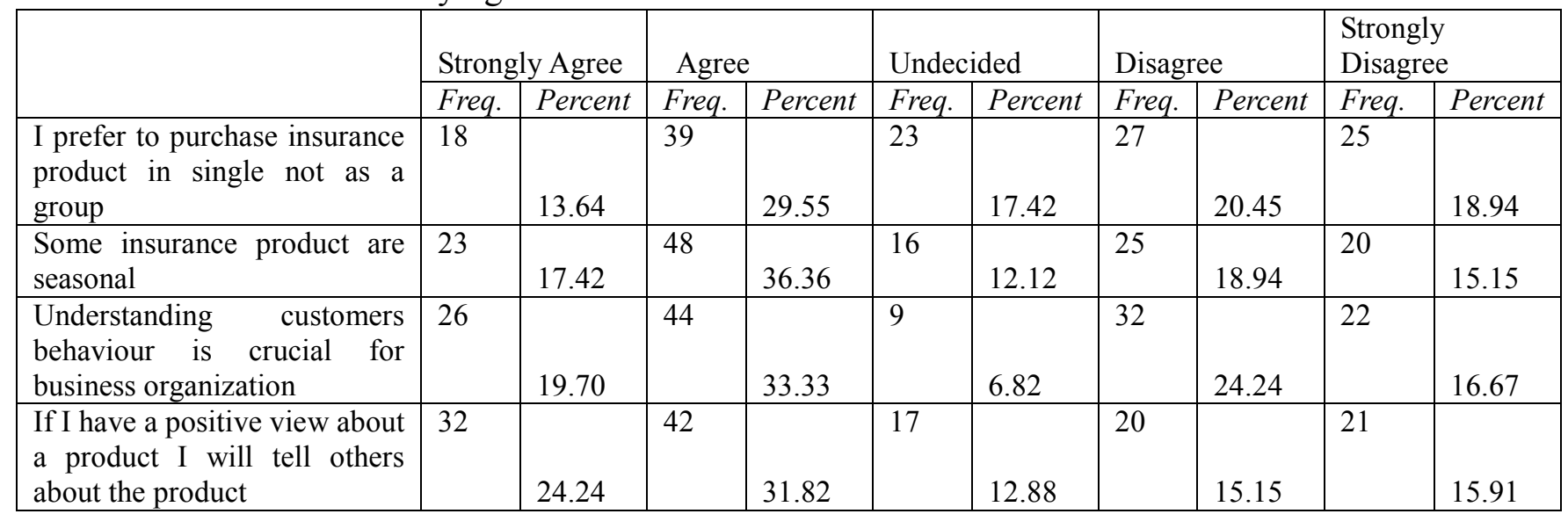

Source: Computed by author. 


\section{Macrothink}

Business and Management Horizons

ISSN 2326-0297

2018, Vol. 6, No. 1

Table 6 reflects the opinion of the people of Lagos State that partook of this study about insurance product; most (43.19\%) of the 132 respondents claimed (Strongly agree and agree) that they prefer to purchase insurance product in single not as a group, $53.78 \%$ of the respondents affirmed that (Strongly Agree and Agree) that "some insurance product are seasonal", 53.03\% of the 132 respondents believed (Strongly Agree and Agree) "understanding customers behaviour is crucial for business organisation" and $56.06 \%$ of the 132 respondents claimed (Strongly Agree and Agree) that if they have a positive view about a product they will tell others about the product.

\subsection{Test of Hypotheses}

4.2.1 $\mathbf{H}_{01}$ : There is no significant relationship between customer's attitude and insurance product

Table 7. Pearson correlation coefficients, $\mathrm{N}=132$; Prob $>|\mathrm{r}|$ under $\mathrm{H} 0$ : $\mathrm{Rho}=0$

\begin{tabular}{|l|l|l|}
\hline & Customer's Attitude & Insurance Product \\
\hline Customer's Attitude & 1.00000 & $0.68563<.0001$ \\
\hline Insurance Product & $0.68563<.0001$ & 1.00000 \\
\hline
\end{tabular}

According to the data presented in Table 7, the correlation between customer's attitude and insurance product is a positive and moderately strong relationship $(\mathrm{r}=0.68563)$. The analysis presented in Table 7 reveals that the relationship between customer's attitude and insurance product is significant since the P-value is $<.0001$. It could be inferred that there is a significant relationship between customer's attitude and insurance product. The relationship is such that, as insurance companies educate customers to better the customer attitude, there will be an increase in the sale of insurance products.

\subsection{2 $\mathbf{H}_{02}$ : There is no significant relationship between product awareness and price}

Table 8. Pearson correlation coefficients, $\mathrm{N}=132$, Prob $>|\mathrm{r}|$ under $\mathrm{H} 0$ : Rho $=0$

\begin{tabular}{|l|l|l|}
\hline & Price & Product Awareness \\
\hline Price & 1.00000 & $0.93133<.0001$ \\
\hline Product Awareness & $0.93133<.0001$ & 1.00000 \\
\hline
\end{tabular}

According to the data presented in Table 8, the correlation between product awareness and price is a positive and very strong relationship $(\mathrm{r}=0.93133)$. The analysis presented in Table 8 reveals that the relationship between product awareness and price is significant since the $\mathrm{P}$-value is $<.0001$. It could be inferred that there is significant relationship between product awareness and price. The relationship is such that, as insurance companies intensify effort on product awareness, so will it be easy to place appropriate price on the product. 
4.2.3 $\mathbf{H}_{03}$ : Promotion of insurance product does not have significant influence on consumers buying behavior.

Table 9. Summary of Regression Analysis of Promotion of Insurance Product on Consumers buying behavior $^{\mathrm{a}}$

\begin{tabular}{|c|c|c|c|c|c|c|c|}
\hline \multirow[b]{2}{*}{ Variable } & \multirow[b]{2}{*}{ Label } & \multirow[b]{2}{*}{$\begin{array}{l}\text { Parameter } \\
\text { Estimate }\end{array}$} & \multirow[b]{2}{*}{ Standard Error } & \multirow[b]{2}{*}{$\begin{array}{l}\mathrm{T} \\
\text { Value }\end{array}$} & \multirow[b]{2}{*}{$\operatorname{Pr}>|t|$} & \multicolumn{2}{|c|}{ Model Summary ${ }^{\mathrm{b}}$} \\
\hline & & & & & & & \\
\hline \multirow[t]{2}{*}{ Intercept } & Intercept & 0.47188 & 0.07981 & 5.91 & $<.0001$ & R-Square & 0.7305 \\
\hline & $\begin{array}{l}\text { Promotion of } \\
\text { Insurance Product }\end{array}$ & 0.64688 & 0.03446 & 18.77 & $<.0001$ & Adj R-Square & 0.7284 \\
\hline
\end{tabular}

Note. a. Predictors: (Constant), Promotion of Insurance Product. b. Dependent Variable: Consumers buying behavior.

Table 9 reveals the degree of influence of benefits of promotion of insurance product on consumers buying behavior; promotion of insurance product influences consumers buying behavior by 73.05 percent, and the remaining 26.95 percent is explained by other things that can influences consumers buying behavior but not included in this particular model.

As depicted in Table 9, the estimates of the model coefficients for $\beta_{0}$ (Intercept) is 0.47188 , and $\beta 1$ (Promotion of Insurance Product) is 0.64688 . Therefore, the estimated model between promotion of insurance product and consumers buying behavior is presented thus:

Consumers buying behavior $=0.47188+0.64688$ Promotion of Insurance Product.

The regression equation shows that promotion of insurance product has a positive relationship with consumers buying behavior. It implies a unit increase in promotion of insurance product will increase consumers buying behavior by 0.64688 . In conclusion, the results of the regression confirm with $95 \%$ confidence that promotion of insurance product has significant influence on consumers buying behavior.

\section{Conclusion}

The aftereffect of this study demonstrates that there is a noteworthy relationship between customer's attitude and insurance product. Low levels of consumption of insurance products requires that insurance companies should enhance their promoting methodologies to counter the problem of poor attitude of prospective consumer. It could also be concluded that "there is a significant relationship between product awareness and price. The result of this research shows that promotion of insurance product has significant influence on consumers buying behavior". To increase the sales of insurance products, the insurance industry should dispatch a gigantic battle that will change people's perception about the industry. They should buckle up on offering a decent image about insurance industry to the overall population through the broad communications. 


\section{Recommendations}

It is along these lines suitable to highlight some proposal which, if executed could assume a critical part in boosting consumer's demeanor on the purchase of insurance products in Nigeria. The following policy considerations are suggested:

- Viability of marketing-orientation instead of selling by insurers should be supported; it will go far in tending to the attitudinal issue of consumers in Nigeria.

- Insurance should present proactive systems that are essentially aimed at educating consumers and empowering more noteworthy use of insurance.

- Learning of the significance and familiarity with insurance has been a serious challenge to the insurance industry. Seminar should be given in business gatherings, educational institutions and open spots to give information about insurance and its products and additionally teaching consumers about the essential of taking insurance.

Amateurish and unwholesome exercises by those selling insurance has created negative perception, in this manner portraying the whole insurance business as bad. In this way, insurance companies should recover their image by creating a sense of security among the customers because of apprehension about the past image of insurance company.

- Insurance companies must guarantee that each genuine claim is paid quickly immediately in indemnification process, while additionally making the entire business of insurance available to the consumers.

- Insurance companies should guarantee that their services are dependable and reliable, in that the services should not require an excessive amount of bureaucratic procedure of their customers in taking an insurance policy or getting their claim.

\section{Reference}

Aduloju, S. A., Awoponle, A. L., \& Oke, S. A. (2008). Recapitalization, Mergers and Acquisitions of Nigeria Insurance Industry. Journal of Risk Finance, 9(5), 449-466. https://doi.org/10.1108/15265940810916111

Aghoghobvia. (2005). Critical Success Factors for Profitable Management of Insurance Institutions. Paper presented at the Nigeria Insurers Association Workshop in Lagos.

Ajzen, I., \& Fishbein, M. (2005). The influence of attitudes on behavior. In D. Albarracín, B. T. Johnson, \& M. P. Zanna (Eds.), The Handbook of Attitudes (pp. 173-222). Mahwah, New Jersey: Lawrence Erlbaum Associates.

Akinbola, O. E., \& Isaac, L. T. (2010). Ethical Issue: A problem in Nigeria insurance companies. School of Management, Blekinge Institute of Technology, Sweden.

Badru, F. A., Yusuf, T. O., \& Ishola, W. (2013). Socio-Cultural Factors Affecting Insurance Patronage in Lagos State, Nigeria: An Exploratory Study. PL ISSN 0239-8818. HEMISPHERES No. $28^{\circ}$. 
Burnett, J. J., \& Palmer, B. A. (1984). Examining Life Insurance Ownership Through Demographic and Psychographic Characteristics. Journal of Risk and Insurance, 51, 453-467. https://doi.org/10.2307/252479

Catalan, M., Gregorio, I. A., \& Alberto, M. (2000). Contractual savings or stock market development, which leads? World Bank Policy Research Working Paper, (12), 24-27.

Delloite. (2017). Retrieved from www.deloitte.com/about

Ebitu, E. T., Ibok, N. I., \& Mbum, P. A. (2012). Factors affecting Insurance Consumption in Akwa Ibom State, Nigeria. Journal of Research in International Business and Management, 2(12), 323-328.

Fishbein, M., \& Ajzen, I. (1975). Belief, attitude, intention and behavior: An introduction to theory and research. Reading, MA: Addison Wesley. F.

Gautam, V., \& Kumar, M. (2012). A study on attitudes of Indian consumers towards insurance services. Management Research and Practice, 4(1), 51-62.

Hammond, J. D., Houston, D. B., \& Melander, E. R. (1967). Determinants of Household Life Insurance Premium Expenditures: An Empirical Investigation. Journal of Risk and Insurance, 34, 397-408. https://doi.org/10.2307/250854

Howcroft, B., Hamilton, B., \& Hewer, P. (2002). Consumer attitude and the usage and adoption of home-based banking in the United Kingdom. International Journal of Bank Marketing, 20(3), 111-121. https://doi.org/10.1108/02652320210424205

Impavido, G., \& Musalem, A. (2000). Contractual savings, stock and asset markets. World Bank Policy Research Working Paper, (12), 46. https://doi.org/10.1596/1813-9450-2421

Lassar, W. M., Manolis, C., \& Lassar, S. S. (2005). The relationship between consumer innovativeness, personal characteristics, and online banking adoption. International Journal of Bank Marketing, 23(2), 176-199. https://doi.org/10.1108/02652320510584403

Lee, J., \& Marlowe, J. (2003). How Consumers Choose a Financial Institution: Decision-Making Criteria and Heuristics. International Journal of Bank Marketing, 21(2), 53-71. https://doi.org/10.1108/02652320310461447

Lewis, B., \& Soureli, M. (2006). The antecedents of consumer loyalty in retail banking. Journal of Consumer Behaviour, 5(special issue), 15-31. https://doi.org/10.1002/cb.46

Ojikutu, R. K., Yusuf, T. O., \& Obalola, M. A. (2011). Attitude and Perception about Insurance Fraud in Lagos State, Nigeria. European Journal of Scientific Research, 57(4), 615-625.

Olaleye, A., \& Adegoke, O. J. (2009). Homeowners perception of insurance of real estate development in Lagos, Nigeria. International Journal of Housing, Markets and Analysis, 2(2), 179-189. https://doi.org/10.1108/17538270910963108 


\section{Macrothink}

Business and Management Horizons

ISSN 2326-0297 2018, Vol. 6, No. 1

Punch.

(2010).

Retrieved

from

www.punchontheweb.com/Articl.aspx?...Art2010030715155545

Solomon, M. (1995). Consumer Behaviour (3rd ed.). New Jersey: Prentice Hall.

Uranta, J. C. (2004). The Development of Oil and Gas in Nigeria. Journal of CIIN, Lagos.

Usman, O. A. (2009). Scale economies and performance evaluation of insurance market in Nigeria. The Social Sciences Journal, 4(1), 1-11.

Yakup, D. (2014). The influence of cultural factors on consumer buying behaviour and an application in Turkey. Global Journal of Management and Business Research: EMarketing, 14(1), 36-44.

Yusuf, T. O., Gbadamosi, A., \& Hamadu, D. (2009). Attitudes of Nigerians Towards Insurance Services: An Empirical Study. African Journal of Economics, Finance and Banking Research, 4(4), 34-46.

\section{Copyright Disclaimer}

Copyright for this article is retained by the author(s), with first publication rights granted to the journal.

This is an open-access article distributed under the terms and conditions of the Creative Commons Attribution license (http://creativecommons.org/licenses/by/3.0/). 